\title{
118. Evidence for Valley Glaciation in Hidaka Mountains, Hokkaido. II
}

\author{
Poroshiri, Esaoman-Tottabetsu Area \\ By Christian SchlÜChter,*) Hans Kerschner, **) \\ and Shoji HoRIE**) \\ (Communicated by Teiichi Kobayashi, M. J. A., Nov. 12, 1985)
}

Introduction. The highest peak area of the Hidaka Mountains around Mt. Poroshiri with neighbouring Nanatsu-numa Cirque and Mt. Esaoman-Tottabetsu has been the focal points of previous paleoglaciation studies in Hokkaido. The existence of a cirque glaciation has been verified and arguments for a multiglaciation hypotheses discussed (Minato and Hashimoto 1954; Horie 1976; Ono and Hirakawa 1975). According to Minato and Hashimoto (1954), a morphogenetic relationship between the glacial record in the cirque area and the terrace sequences in lower reaches of the Esaoman-Tottabetsu Valley is established. The following communication reports on the results by a first expeditionary survey to the area in the summer of 1983.

Morphology. The restriction of cirque morphology to northerly, northeasterly, easterly and south-easterly slopes of the highest peaks and adjacent ridges is, obviously, a more theoretical than real argument (Minato and Hashimoto 1954; Horie 1976; Ono and Hirakawa 1975). Cirque morphology is present in the uppermost southern slopes of Mt. Poroshiri as well (Fig. 1). These southern forms are less developed than Nukabira- or Nanatsu-numa Cirque and have therefore, not been recognized so far. On the other hand no evidence has been found to support the believe that cirque morphologies of a different stage of freshness or of different altitude would correspond to glaciations of different age. E.g. the morphology of Nanatsu-numa cirque is mainly bedrock lithology controlled and influenced by an active fault system.

Trough-like features such as parabolic cross sections, shoulders and hanging valleys are to be mapped in the valleys to the south of Mt. Poroshiri as far downvalley as the Poroshiri Reservoir lake. The same holds true for EsaomanTottabetsu Valley where forms of glacial erosion can be traced downvalley to about $750 \mathrm{~m}$. Terrace relics which accompany in same places the EsaomanTottabetsu River a few meters above the actual river course do not necessarily belong to fluvioglacial activity in a strict sense. As the bed rock topography is complex with regard to the actual river the relic accumulation terraces more logically are attributed to the local erosional evolution of the river long profile.

Well preserved moraine forms are mainly restricted to the "classically known" cirques around Mt. Poroshiri and Mt. Esaoman-Tottabetsu. However, well developed and preserved moraine forms exist at lower altitudes (Fig. 1).

*) Institute of Foundation Engineering and Soil Mechanics, ETH-Hönggerberg, Zürich, Switzerland.

**) Institute of Geography, University of Innsbruck, Innsbruck, Austria.

***) Institute of Paleolimnology and Paleoenvironment on Lake Biwa, Kyoto University. 


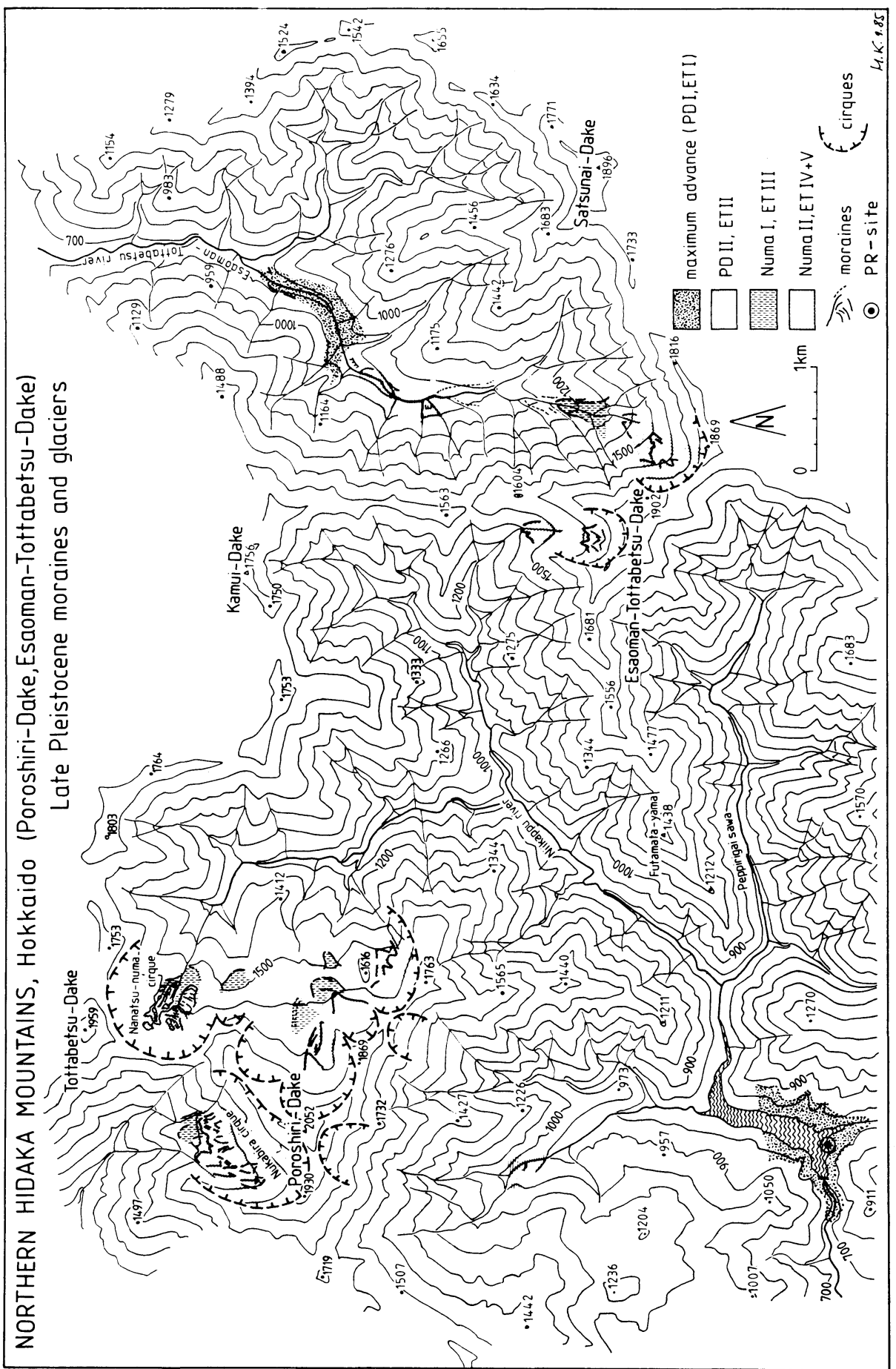

Fig. 1. Glacial geological sketch map of Mt. Poroshiri/Mt. Esaoman-Tottabetsu area. 
These are mainly lateral ice marginal terrace-systems (Fig. 1). Only at one site (at approximately $850 \mathrm{~m}$ in Tottabetsu Valley) a more frontal ridge is preserved in association with the onset of an external valley train (Fig. 1, Stage ET II). To the south of Mt. Poroshiri ice-marginal accumulations with a recognizable morphology are located between 900 and $950 \mathrm{~m}$ (Fig. 1, Stage PD II).

The moraine ridges in the cirque area to the east of Mt. Poroshiri and in Nanatsu-numa and in Nukabira cirque are subdivided in two different groups of preservation: An internal set of ridges (= Stage Numa II, ET IV + V, Fig. 1) is of fresh undisturbed appearance, wherelse the external (and hence, older) set displays considerable periglacial modification (= Stage Numa I, ET III, Fig. 1). An attempt has been made to reconstruct the glaciers which formed the moraine ridges described so far and given in Fig. 1. Based on such a reconstruction the following equilibrium line altitudes ("snowlines") have been calculated (using the methods described by Nye 1952; Gross, Kerschner and Patzelt 1978; Kerschner 1979):

\begin{tabular}{lcllr}
\hline \multicolumn{2}{c}{ Esaoman-Tottabetsu Valley } & \multicolumn{2}{c}{ Poroshiri-Dake Area } \\
\cline { 4 - 5 } ET I (maximum) & $1190 \mathrm{~m}$ & & PD I (maximum) & ca. $1250 \mathrm{~m}$ \\
ET II & $1300 \mathrm{~m}$ & & PD II & ca. $1350 \mathrm{~m}$ \\
ET III & $1470 \mathrm{~m}$ & & Numa I & $1630 \mathrm{~m}$ \\
ET IV & $1540 \mathrm{~m}$ & & Numa II & $1660 \mathrm{~m}$ \\
ET V & $1620 \mathrm{~m}$ & & \multicolumn{2}{c}{ Nukabira Cirque } \\
\cline { 4 - 5 } Cirque N of Esaoman-Tottabetsu & & \multicolumn{2}{c}{$1630 \mathrm{~m}$} \\
ET IV & $1550 \mathrm{~m}$ & & Numa I & $1730 \mathrm{~m}$ \\
ET V & $1670 \mathrm{~m}$ & & Numa II
\end{tabular}

Thus the comparison in altitude of correlative moraine ridges (Fig. 1) demonstrates that the equilibrium line altitude is rising distinctively from $\mathrm{E}$ to $\mathrm{W}$.

Glacial sediments and related deposits. Only one site in the study area comprises a glacial sediment complex of stratigraphic importance: the PoroshiriReservoir site (PR-site, Fig. 1). Within the fluctuation zone of the lake level a highly complex sedimentary sequence overlies a weathered, decomposed basal till. Immediately above the till several meters of sandy-silty gravel follow. This fluvial/glaciofluvial accumulation itsef is overlain by two meters of silty sand with occasional boulders and with interbedded laminated clayey silt. The uppermost fine-grained complex contains a considerable amount of pumice.

This site is important in comparison to a roadcut $4 \mathrm{~km}$ downvalley from the reservoir dam. There, a pumice-sequence is observed which displays a macro- and microscopic similarity to the Poroshiri-Reservoir (= PR-) site. And at the downvalley outcrop the pumice deposits are extremely loose and unstable wherelse at the PR-site they are compact. Glacial overriding and compaction has, most probably, occurred at the PR-site. The difference in outcrop characteristics is striking. In addition to the argument of compactness frequent nonweathered erratic boulders occur in the vicinity of the PR-site on the weathered bed rock surface. As well the form and petrography as also the very existence of the boulders in this area point to a glacial advance to this point after the deposition of the pumice.

Stratigraphy. Preliminary pollen analytical work at two samples from the fine grained laminae in the upper parts of the gravel overlaying the till at the PR-site indicate a vegetation type corresponding to cooler climatic con- 
ditions (Pinus, Betula, Ericaceae). Of stratigraphic relevance is a fission-track date on the pumice at the downvalley occurrence with an age of $0.06 \pm 0.03 \mathrm{Ma}$ (Million years). Considering the compactness of the pumice-bearing bed at the PR-site, therefore, a glacial advance younger than 30,000 years BP. (as a minimum age) has occurred. A detailed investigation on the position of the pumice recorded here in the Hokkaido tephrochronology and especially its relationship to the "Spfa-family" is under way.

Summary and conclusions. The existence of a valley glaciation in the Mt. Poroshiri/Mt. Esaoman-Tottabetsu is demonstrated (Fig. 1). The maximum glacier extent to about $700 \mathrm{~m}$ in this area is in agreement with the results in the Satsunai Valley (Schlüchter et al. in this proceeding). The stratigraphic results from the PR-site in relation to the occurrence of pumice beds indicate that the glacier systems discussed here belong to the Last Glaciation: ET I and PD I (Fig. 1) being the maximum and the stages ET II to ET V correspond to phases of readjustment during overall retreat. This view is also supported by the morphological consideration that accumulative landforms in such a highenergy environment are subject to constant modification and, therefore, cannot be too old. It has also become evident that southerly slopes did produce glaciers in this part of the Hidaka Mountains during the Pleistocene. Calculated depressions of the respective equilibrium line altitudes are in agreement with the results from Satsunai Valley. The believe in a morphogenetic relationship between the moraine ridges in the cirque areas and the terraces in lower reaches of the valleys cannot be maintained.

Acknowledgements. Formal thanks are due (1) to the Swiss Academy of Natural Sciences for a travel grant to the first author and (2) to the Japan Society for the Promotion of Science for a grant to the second author. We also express our best thanks to Prof. N. Fuji, Kanazawa University, for pollen analytical work and to Dr. Keiji Takemura for the tephra analysis.

\section{References}

Gross, G., Kerschner, H., and G. Patzelt (1978): Methodische Untersuchungen über die Schneegrenze in alpinen Gletscher-gebieten. Zeitschr. f. Gletscher-kde. Glazialgeol., $12,223-251$.

Horie, S. (1976) : Glacial Features on Japanese High Mountains (Part 3). Paleolimnology of Lake Biwa and the Japanese Pleistocene (ed. S. Horie), 4, 11-30.

Kerschner, H. (1979) : Zur Rekonstruktion eines Spätglazialen Gletscherstandes mit Hilfe eines rechnerisch ermittelten Zungenlängenprofiles. Zeitschr. f. Gletscher-kde. Glazialgeol., 14, 119-123.

Minato, M., and S. Hashimoto (1954): Zur Karbildung im Hidaka-Gebirge, Hokkaido, Japan. Proc. Imp. Acad., 30, 106-108.

Nye, J. F. (1952): A comparison between the theoretical and the measured long profile of the Unteraar Glacier. Jour. Glaciol., 2, 103-107.

Ono, Y., and K. Hirakawa (1975): Glacial and Periglacial Morphogenetic Environments around the Hidaka Range in the Würm Glacial Age. Geogr. Rev. Japan, 48, $1-26$. 